\title{
ERRATA
}

\section{Protoplast Transformation in Coryneform Bacteria and Introduction of an $\alpha$-Amylase Gene from Bacillus amyloliquefaciens into Brevibacterium lactofermentum}

MICHAEL D. SMITH, JEANNETTE L. FLICKINGER, DONALD W. LINEBERGER, AND BRIAN SCHMIDT

Genex Corporation, Gaithersburg, Maryland 20877

Volume 51, no. 3, p. 638, Acknowledgments, line 7: “David Anderson” should read “James J. Anderson.”

\section{Evaluation of Different Assay Systems for Identification of Environmental Aeromonas Strains}

\author{
ALICIA E. TORANZO, YSABEL SANTOS, TERESA P. NIETO, AND JUAN L. BARJA
}

Departamento de Microbiología, Facultad de Biología, and Colegio Universitario de Orense, Universidad de Santiago de Compostela, Santiago de Compostela, Spain

Volume 51, no. 3, p. 655 , line 17-18: “. . . the results are clear and simple to score after the same time of incubation” should read ". . . the results must be scored for all tests at the time of incubation, which is not usually possible for environmental strains."

Page 655, Acknowledgments: This section should include "This work was supported by grant AQ-0018/84 from the Comision Asesora de Investigación Cientifica y Técnica (CAICYT), Ministerio de Educacion y Ciencia, Spain.” 